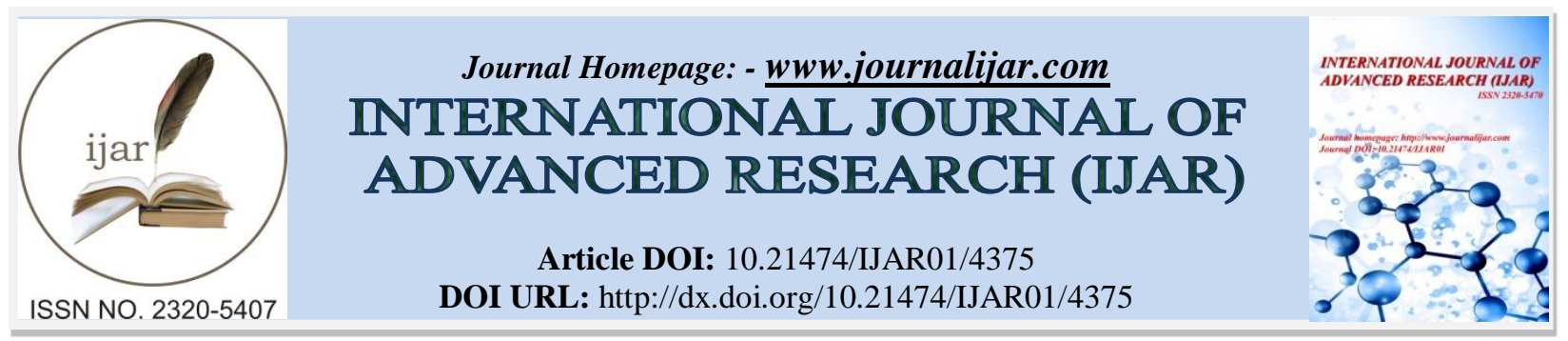

RESEARCH ARTICLE

\title{
SPATIAL VARIATION OF BIOMARKERS IN MUSSELS MYTILUS GALLOPROVINCIALIS FROM THE MOROCCAN ATLANTIC CENTER COAST.
}

\section{Zbiry ${ }^{1}$, B. Elhaimeur ${ }^{2}$, M. Bouhallaoui ${ }^{2}$, S. Talba ${ }^{3}$, M. Bekkali ${ }^{1}$, J. F. Férard ${ }^{4}$ and A. Benhra ${ }^{2}$.}

1. Ain Chock Faculty of Sciences, Biology department, Casablanca, Morocco.

2. National Institute of Fischeries Research (INRH), Casablanca, Morocco.

3. Ben Msik Faculty of Sciences, Casablanca, Morocco.

4. Lorraine University (UdL), Interdisciplinary Laboratory of Continental Environments (LIEC) - UMR 7360 CNRS, Metz, France.

\section{Manuscript Info}

\section{Manuscript History}

Received: 01 april 2017

Final Accepted: 03 june 2017

Published: june 2017

Key words:-

AChE, Biomarkers, Ecotoxicology, GST, MDA, MT, Mytilus

galloprovincialis,

\section{Abstract}

In this study, four biomarkers, Acetylcholinesterase (AChE), Glutathione-s-transferase (GST), Metallothioneines (MT) and Malondialdehyde (MDA) were measured, during spring 2013, in indigenous mussels Mytilus galloprovincialis from five sites of Moroccan Atlantic center coast, subjected to the impact of anthropogenic activities.

The results show a general stress in the studied area, with three groups of stations. The first one includes mussels from station S1 with low MDA and MT activities. The second encompasses the most polluted stations (S4 and S5) with high MT and MDA activities as well as low $\mathrm{AChE}$ and high GST activities. Lastly, mussels from the least polluted stations (S2 and S3) characterized by moderate MDA and MT levels, low GST and high AChE activities. The results indicate that the biochemical alterations observed in the mussel digestive gland could be used as suitable biomarkers for evaluating environmental quality of the media based on the biological assessing methods and can provide early warning information on the impact of contaminants on marine environment.

Copy Right, IJAR, 2017,. All rights reserved.

\section{Introduction:}

The Moroccan coast is a highly attractive area that is experiencing a demographic explosion associated with untreated urban and industrial rejections in the marine environment. Human activities (agriculture, industry, port activities) developed in this area are the undisputed source of various pollutants.

The aquatic environment is affected by different types of toxic chemicals like PCBs, heavy metals, pesticides and PAHs. Many organic contaminants and heavy metals enter readily to food chains and tend to bioaccumulate, while some of them are rapidly metabolized (McCarthy and Shugart, 1990; Livingstone et al., 1992; Livingstone, 1993). To assess the environmental impact of these pollutants, chemical analyses are generally performed. But contaminants usually occur in the environment as complex mixtures that can cause interactive effects on the biota that are impossible to evaluate through chemical analyses alone. In this sense, biomarkers offer an integrated 
assessment of exposure levels and effects of pollutants in wildlife. As it is increasingly recognized that assessment of environmental disturbances requires the understanding of effects at the ecosystem level, from the molecular and cellular to the individual, population and community levels, the use of ecologically relevant biomarkers is required (Cossu-Leguille and Vasseur, 2013).

There are several biomarkers that are more specific for certain types of compounds and, thus, the inclusion of the use of a battery of biomarkers has been strongly recommended in monitoring programs (McCarthy et al. 1990; Labrot et al., 1996; Mora et al., 1999; Narbonne et al., 1999; OSPAR, 2000; ICES, 2008). However, the interest and usefulness of the biomarker approach is related to the choice of sentinel species. Among sentinel species, mussel is one of the most suitable species because they have the ability to accumulate and concentrate pollutants (Jeng et al., 2000).

In this study, four biomarkers were selected. Acetylcholinesterase (AChE) is an enzyme involved in the synaptic transmission of nerve impulses. It was chosen because its inhibition has been used in some coastal biomonitoring programs as a biomarker of organophosphate and carbamate pesticide exposure in bivalves (Galgani \& Boquené 1989, Binelli et al. 2006) and also by other contaminant such as heavy metals, synthetic detergents, some component of fuel oils and algal toxins (Guilhermino et al., 1998; Lehtonen et al., 2003; Tim-Tim et al., 2009). Glutathione Stransferase (GST) is an important phase II enzyme involved in the detoxification of organic toxicants (Habig et al., 1974). It is often used to assess the oxidative stress induced by chemicals (He et al., 2011). Thus it is particularly interesting to associate the study of GST activity to an oxidative damage assay, such as MDA concentration. Malondialdehyde (MDA) is the product of lipid peroxidation due to an overproduction of oxyradicals in cells, following contaminant exposure or stress due to natural conditions (Pellerin-Massicotte, 1997). Lipid peroxidation is considered as an important feature in cellular injury and MDA is widely used as reflecting the state of lipid peroxidation of the membrane (Knight et al., 1988). It results from free radical reactions in biological membranes, which are rich in polyunsatured fatty acids. MDA has been used to assess effects of various pollutants (Viarengo and Canesi, 1991; Pellerin-Massicotte, 1997). Metallothioneins (MTs) play an important role in metal metabolism (Langston et al., 1998) and also in oxidative stress (Thornalley and Vašák, 1985). It is interesting to associate the study of cellular toxicity indicators (MDA) and antioxidant molecules (MT).

The objective of our study was to evaluate a set of biomarkers in the digestive gland of the mussel Mytilus galloprovincialis and to assess their spatial variability. In addition, environmental parameters - $\mathrm{pH}$ and temperature were quantified in water samples, in order to investigate the possible effects of these variables on biomarkers responses. This kind of study is geographically and temporally limited to an industrial coastal axis but can provide valuable information to evaluate the potential of biomarkers for environmental quality assessment. 


\section{Materials and Methods:- \\ Study area and sampling:-}

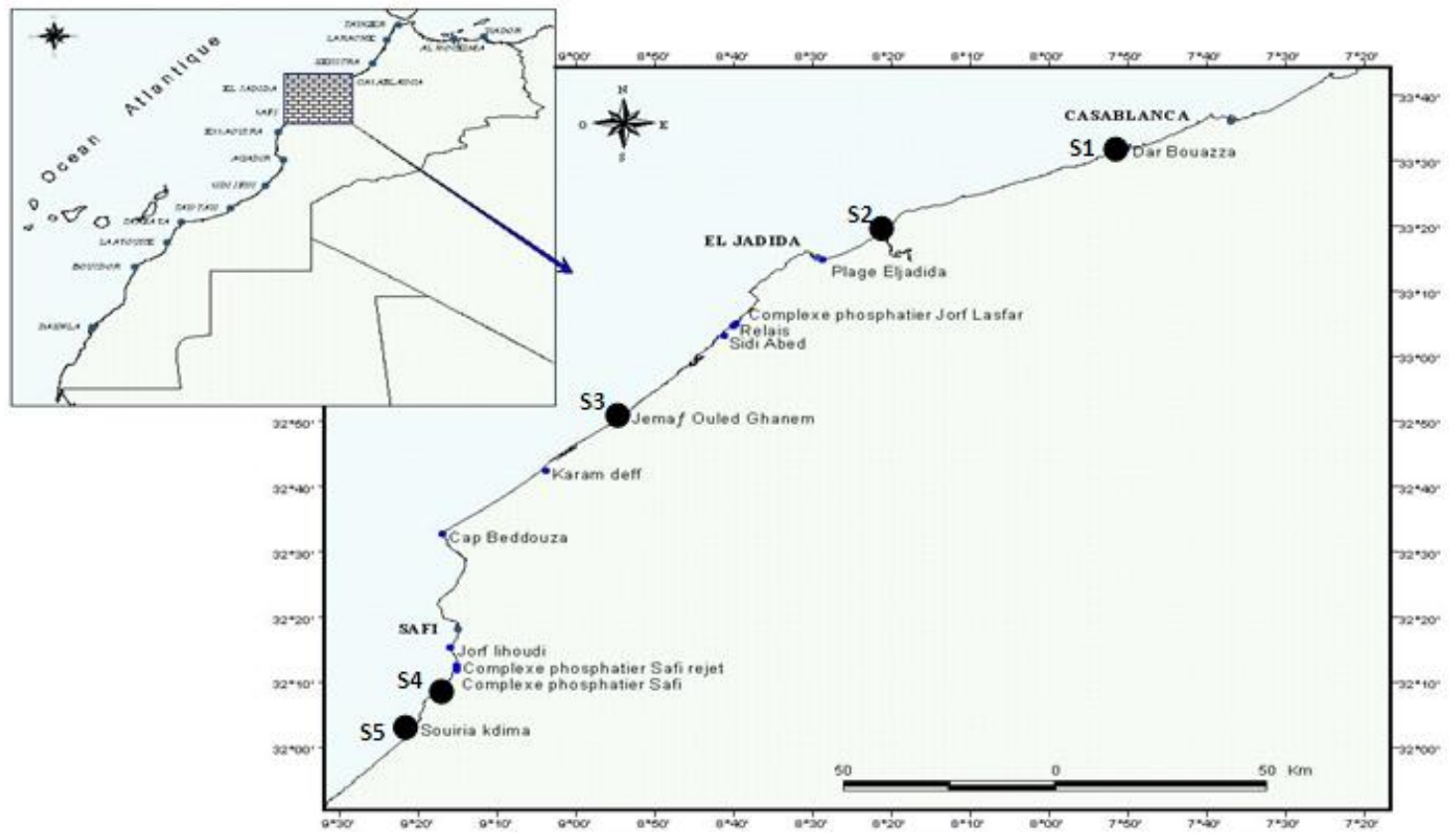

Fig 1:- Map of sampling sites at the Moroccan Atlantic center coast

For our study, we have chosen five sampling sites (S1-Dar Bouazza, S2-Azzemour, S3-Jemaat ouled ghanem, S4-

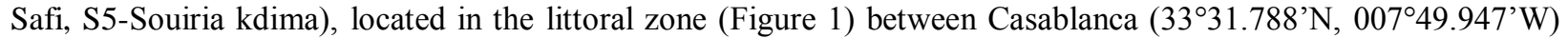
and Safi $\left(32^{\circ} 05.038^{\prime} \mathrm{N}, 009^{\circ} 34.316^{\prime} \mathrm{W}\right)$ in the Moroccan Atlantic-center coast. This area is bordered in the hinterland by Doukkala's agricultural plain where industrial units are also established. In this sector, the marine environment is used as a final repository for discharges of urban, agricultural and industrial wastewaters. As regards the currents study in this area, the Moroccan Atlantic coast is exposed to a high energy characterized by swells from the North Atlantic, mainly originally from West Northwest (Charouf, 1986).

\section{Biological Material:-}

Mussels (M. galloprovincialis) with the same length $(45 \pm 5 \mathrm{~mm})$ from the same population were collected manually in spring 2013, from the sampling sites and transferred to the laboratory. Temperature and $\mathrm{pH}$ were measured at the sampling sites.

After collection, mussels were transported in a cold container to the laboratory, digestive glands were cut out of the shells. For biochemical analyses, digestive gland samples were conserved until analysis at $-80^{\circ} \mathrm{C}$. For the analysis, samples are thawed on ice and homogenized with an Ultra-Turrax tissue homogenizer in 1:3 (v:v) $100 \mathrm{mM}$ phosphate buffer, $\mathrm{pH} 7.4$ for AChE, GST and MDA measurements. Homogenates were centrifuged at 9000g for $30 \mathrm{~min}$. All preparation procedures were carried out at $4^{\circ} \mathrm{C}$ (in ice). After centrifugation, the supernatant (fraction S9) was used for biomarkers analyses.

\section{Biochemical Determinations:-}

All assays were performed in triplicate. Protein concentrations were determined according to the Bradford (1976) colorimetric method using bovine serum albumin (BSA) as standard.

The AChE activity was determined using the Ellman et al. (1961) method with the use of acetylthiocholine (ATCh) $0.075 \mathrm{M}$ as a substrate. The method is based on the increase in yellow colour produced due to the reaction of thiocholine with 5,5'-dithiobis-(2-nitrobenzoic acid) $0.01 \mathrm{M}$ during ATCh hydrolysis by AChE. The activity rate was measured as change in $\mathrm{OD} / \mathrm{min}$ at $412 \mathrm{~nm}$. Activity was expressed as $\mathrm{nmol} / \mathrm{min} / \mathrm{mg}$ protein. 
The GST assay was performed using Habig et al. (1974) method. GST activity was measured spectrophotometrically. The activity rate of GST was measured as the change in OD/min at 340nm and expressed as $\mathrm{nmol} / \mathrm{min} / \mathrm{mg}$ protein.

MDA concentrations were estimated according to the method described by Sunderman et al. (1985) with the use of tetramethoxypropane as a standard. The reaction products were determined at 532nm, using thiobarbituric acid as reagent. MDA contents were expressed as $\mathrm{nmol} / \mathrm{mg}$ wet weight.

The metallothionein (MT) content was analysed according to the method of Viarengo et al. (1997). The method is based on the estimation of MT by spectrophotometric determination of thiol groups using Ellman's reagent. MT concentration is calculated utilizing reduced glutathione (GSH) as reference standard and expressed as MT/g fresh weight tissue. This reaction is determined at $412 \mathrm{~nm}$.

\section{Statistical treatment of Data:-}

Results of all parameters were reported as mean \pm standard deviation. The variation of each parameter among sites was tested by two-way ANOVA $(\mathrm{p}<0.05)$. Previously we tested the pre-requisites for analysis of variance (normality and homogeneity of variances). When significant differences were found, Tukey's test was applied to determine which values differed significantly.

Linear Pearson correlations were used to examine dependencies between biomarkers and abiotic parameters ( $\mathrm{p}<0.05)$. Principal component analysis (PCA) was performed on four biomarkers (AChE, GST, MDA and MT) and the abiotic parameters (temperature and $\mathrm{pH}$ ). All statistical analyses were performed with XLSTAT Version 2014.4.06.

\section{Results:-}

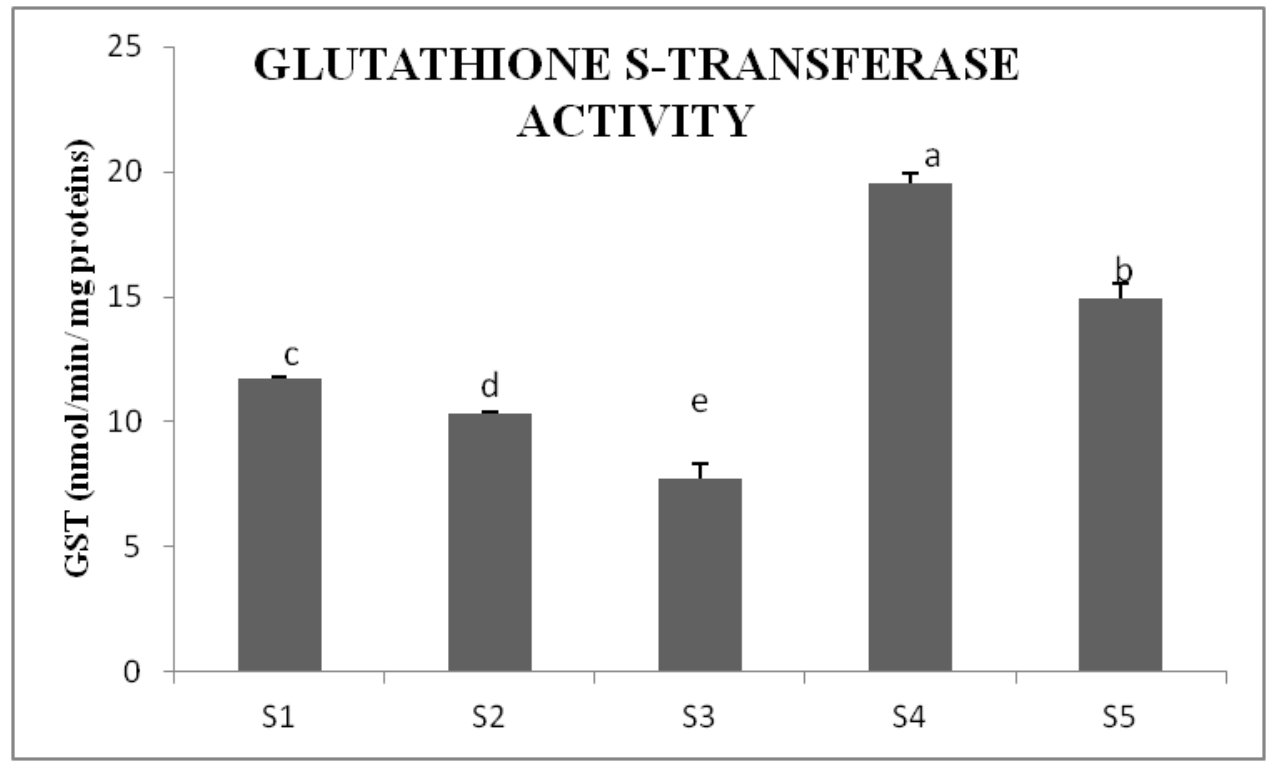

Fig 2-a: Glutathione S-transferase activity (expressed as nmol/min/mg proteins) in digestive gland of mussels (Mytilus galloprovincialis) during spring 2013 from Moroccan atlantic center coast (mean \pm s.d., $n=3$ ). Data were analyzed by ANOVA + Tukey's test (letters above columns indicate statistical significance, $\mathrm{p}<0.05$ ). 


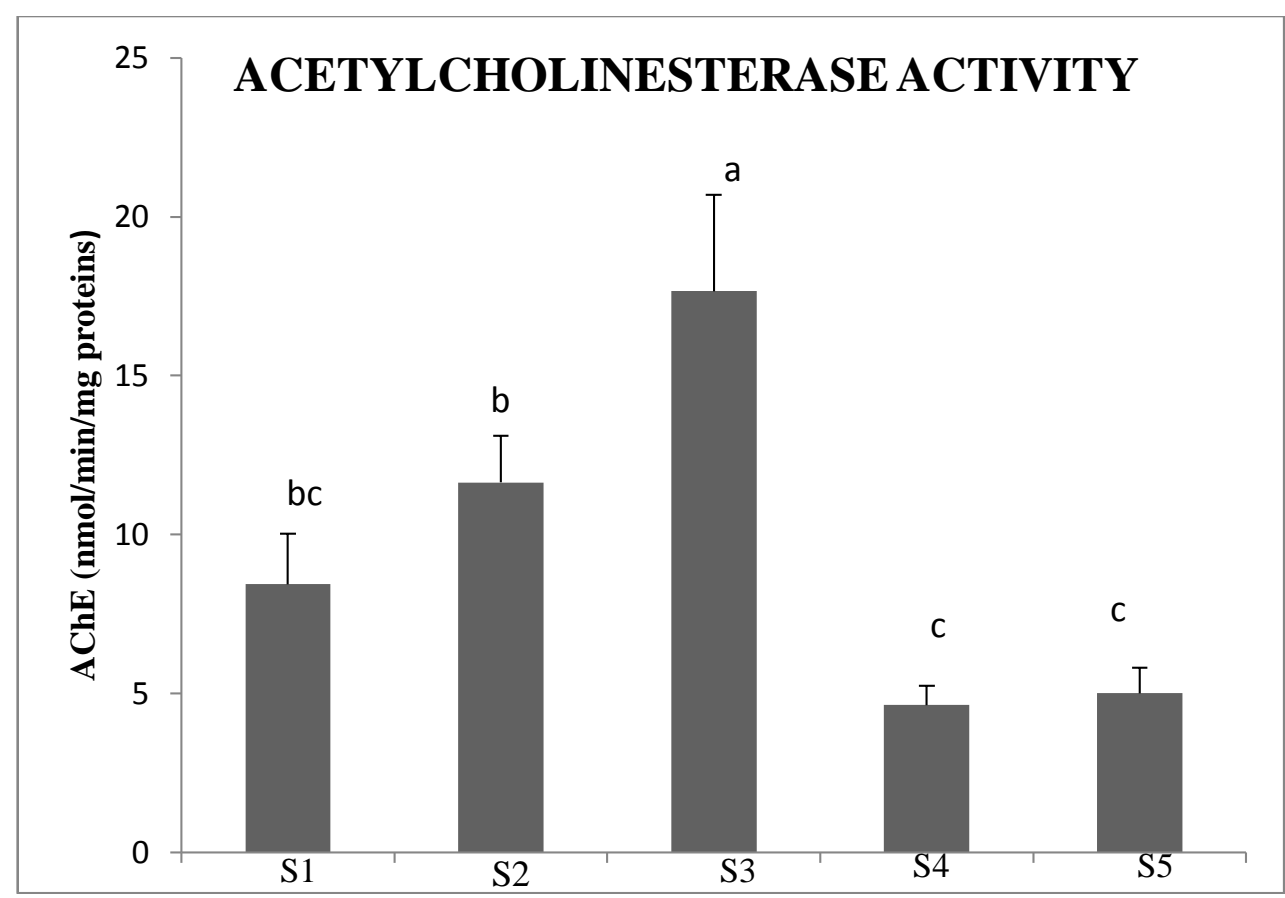

Fig 2b: Acetylcholinesterase activity (expressed as $\mathrm{nmol} / \mathrm{min} / \mathrm{mg}$ proteins) in digestive gland of mussels (Mytilus galloprovincialis) during spring 2013 from Moroccan atlantic center coast (mean \pm s.d., $n=3$ ). Data were analyzed by ANOVA + Tukey's test (letters above columns indicate statistical significance, $\mathrm{p}<0.05$ ).

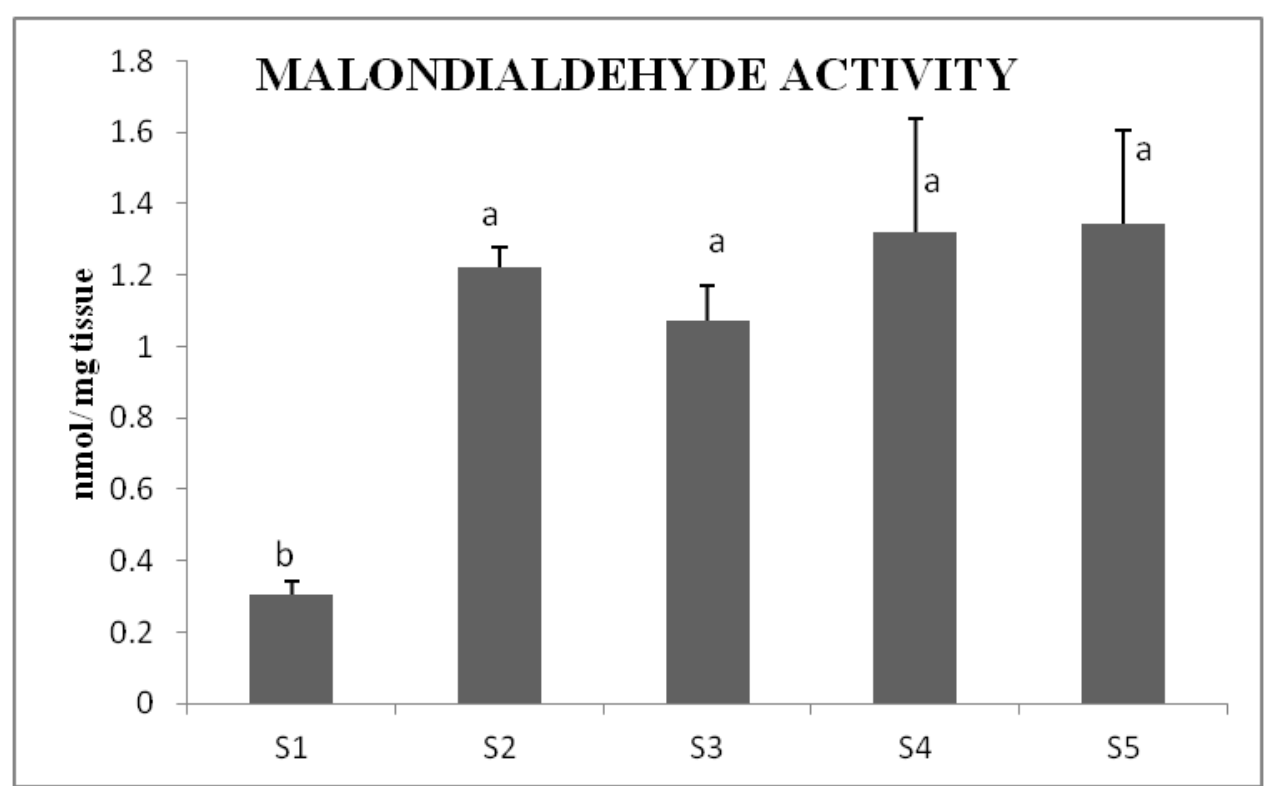

Fig 2c:- Malondialdehyde (as $\mathrm{nmol} / \mathrm{mg}$ tissue) in digestive gland of mussels (Mytilus galloprovincialis) during spring 2013 from Moroccan atlantic center coast (mean \pm s.d., $n=3$ ). Data were analyzed by ANOVA + Tukey's test (letters above columns indicate statistical significance, $\mathrm{p}<0.05$ ). 


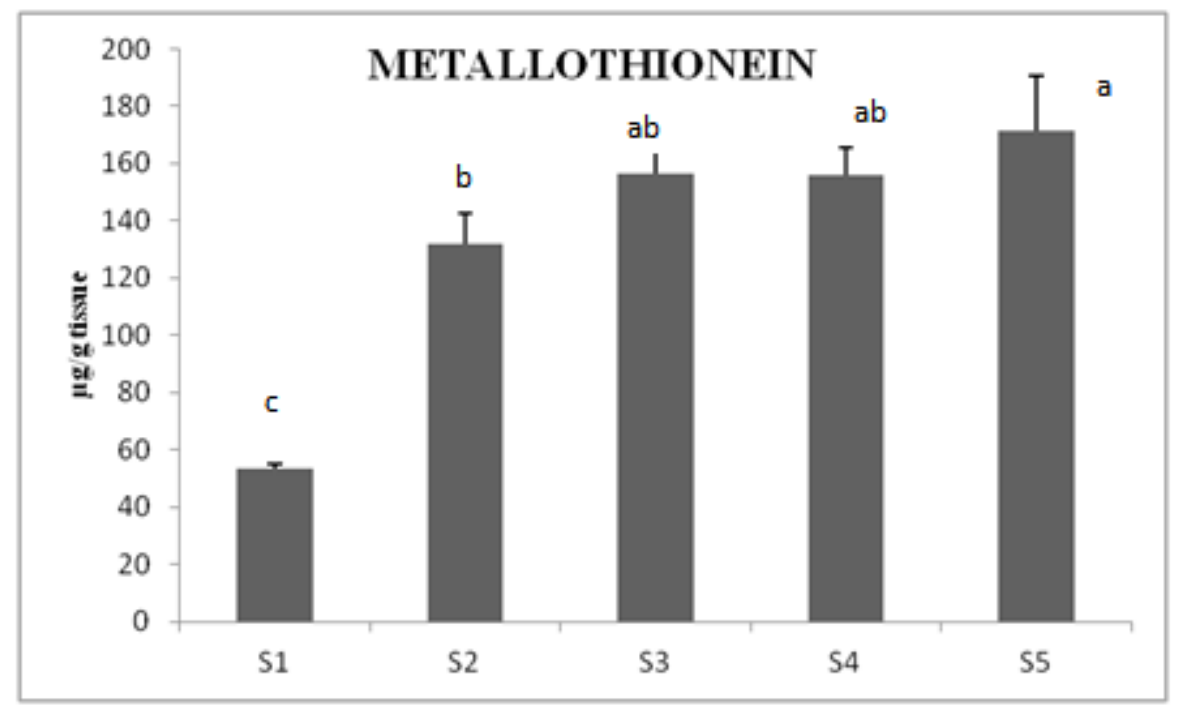

Fig 2d:- Metallothionein (as $\mu \mathrm{g} / \mathrm{g}$ tissue) in digestive gland of mussels (Mytilus galloprovincialis) during spring 2013 from Moroccan atlantic center coast (mean \pm s.d., $n=3$ ). Data were analyzed by ANOVA + Tukey's test (letters above columns indicate statistical significance, $\mathrm{p}<0.05$ ).

GST and AChE activities showed that the most significantly impacted sites were S4 and S5 with the highest GST values and lowest $\mathrm{AChE}$ values (Figures 2a and 2b). More precisely, GST concentrations were significantly higher $(\mathrm{p}<0.05)$ than others in mussels coming from S4 and S5, respectively with values $19.55 \pm 0.36$ and $14.92 \pm 0.03$ (Figure 2a). The lowest activity (7.72 \pm 0.59$)$ was recorded in S3 (Figure 2a).

Very low AChE concentrations (Figure 2b) were found in mussels coming from S4 and S5 respectively with values $4.63 \pm 0.59$ and $5.0 \pm 0.8$, these values were significantly lower $(\mathrm{p}<0.05)$ than others. Highest AChE values concentration were found in S3 (17.66 \pm 3.03$)$.

Figure 2c shows that MDA concentration S1 $(0.30 \pm 0.04)$ was significantly lower than others. No significant differences were observed between other sites $(\mathrm{p}<0.05)$. The highest value $(1.34 \pm 0.26)$ was found in mussels from S5. Figure $2 \mathrm{~d}$ also shows high MT concentrations in mussels from all the stations with no significant differences $(\mathrm{p}<0.05)$ between sampling sites, except for mussels from S1 $(53.28 \pm 19.03)$. The highest value $(171.32 \pm 19.02)$ was recorded in mussels from S5. MDA and MT levels showed that all the study areas, except S1, were impacted by contaminants.

\section{Discussion:-}

Biomonitoring programs based on measuring contaminants in marine organisms are interesting. However measuring pollutant concentrations in sea water presents some disadvantages such as the low concentrations and the random spatial and temporal variations (Hamza-Chaffai, 2014). Moreover, the cost-efficiency of the biomarker approach has been highlighted by some authors (Hagger et al., 2006; Capela et al., 2016).

It is well known that Morocco is the second phosphate producer in the world. 27 million tons of phosphate ores are extracted and processed annually (Office Chérifien des Phosphates, 2012). Thus, the Moroccan phosphate industry releases large amounts of organophosphogypses which are rich in cadmium in the North-West (NW) African upwelling around Safi and Jorf-Lasfar $\left(33^{\circ} \mathrm{N}\right)$. Locally, these are responsible for a significant contamination of coastal mollusk communities (Cheggour et al., 1999; Chafik et al., 2001; Benbrahim et al., 2006; Maanan, 2007, 2008). As a consequence, mussels for instance were considered unfit for human consumption in this region (Moustaid et al., 2005).

Several studies have reported GST increases in mussels exposed to metals (Canesi et al., 1999; Khessiba et al., 2001) or collected from metal-polluted sites (Torres et al., 2002; Won et al., 2005; Fernández et al., 2010; VidalLiñán et al., 2010). Some field studies have also reported a significant induction of GST activity in mussels exposed to organic compounds (Moreira and Guihermino, 2005; De Luca-Abbott et al., 2005). Jayed et al. (2010) reported 
that of 13 sampling points throughout the Moroccan Atlantic coast, the highest DDT and PCBs levels were recorded in mussels collected from 3 stations that fit our sampling points S1, S3 and a point located between both. Parolini et al. (2013) noticed a significant correlation between induction of GST and $\Sigma$ DDTs in soft tissues from Zebra mussel (Dreissena polymorpha) exposed to an organochlorine mixture. Safi matches S4 and Jorf-Lasfar is located between S2 and S3. So, we can assume that our study area may not only be impacted by DDTs and PCBs, but also by metals, such as cadmium.

AChE is an enzyme involved in recycling of acetylcholine, a neuromediator of cholinergic nerves. Numerous studies reported AChE inhibition by various neurotoxic compounds such as organophosphate and carbamate pesticides (Fulton and Key, 2001). AChE inhibition has thus been suggested as indicative of general neurotoxic stress (Lehtonen et al., 2006). Our results (Figure 2b) showed low AChE activities at sites influenced by agricultural practices where pesticide contamination could be expected (S1, S2), but also very low AChE activities at sites S4 and S5, i.e. areas receiving urban and industrial waste of phosphate treatment. In S3, which is located far from urban and industrial sources of pollution, high $\mathrm{AChE}$ activity was recorded, which could indicate a lower level of contamination on this site. This AChE activity level was similar to those obtained by Mora et al. (1999) on M. galloprovincialis collected from a low polluted site at the entrance of Arcachon bay (southwest France). When compared with data from the literature, the values of our study (17.66 \pm 3.03$)$ are in the same range as those recorded by Barhoumi et al. (2014) in mussels collected from the Bizerte lagoon (Tunisia) and by Serafim et al. (2011) in mussels collected from the south coast of Portugal.

Lipid peroxidation is a well-known mechanism of cellular injury in vertebrates and invertebrates, and is an indicator of an oxidative damage in cells and tissues. MDA can react readily with amino groups on proteins and other molecule to form a variety of adducts (Marnett, 1999). It is known that lipid peroxidation in mussel digestive gland can be stimulated via oxidation of polyunsaturated fatty acids, not only by various inorganic cations such as $\mathrm{Cu}, \mathrm{Cd}$, $\mathrm{Ag}$ and $\mathrm{Hg}$ (Viarengo et al., 1990; Géret et al., 2002). Our results showed an increase of MDA in all the sites, except for S1 which is far from contamination sources (Figure 2c). It is important to mention that the initial products of polyunsatured fatty acid oxidation are peroxyl radicals. When a cell or a tissue is not able to prevent oxidative damage, there is an increase of lipid peroxidation, measured as an increase in MDA, and this reaction may occur in mussels from S2 to S5.

MT could protect cells from oxidative damages and is considered as a biomarker of exposure to heavy metals not only by acting as an oxyradical scavenger, but also through metal binding/release dynamics (Viarengo et al., 2000). Moreover, metals are known to produce reactive oxygen species (ROS) (Viarengo et al., 1990; Stohs et al., 2000). ROS can act on membrane lipids leading to lipid peroxidation and to the formation of MDA. However, MT could protect cells against toxic effects of ROS (Viarengo et al., 2000, Andrews, 2000). In this study, MT concentrations increase from S1 to S5, with high concentrations in all the study area except for S1. We have noted in this study that MT and MDA content progress in the same way (Pearson correlation coefficients showed a significant correlation between MDA and MT), with lowest values in S1 and the concentrations increase from S2 to S5. The increase of MDA levels is associated to increase of MT levels. This increase could result in a saturation of antioxidant system by heavy metals.

The studied sites represent various environmental conditions and are differently affected by pollutants. The diffused contamination of PCBs, DDTs and heavy metals in this area is well known (Cheggour et al., 1999; Kaimoussi et al., 2000; Chafik et al., 2001; Bouthir et al., 2004; Jayed et al., 2010) and a clean site has not yet been adequately identified.

The results showed an increase in MT and MDA activities in all the studied area (except S1), a decrease in AChE activity and an increase in GST activity in mussels from S4 and S5, this could be due to environmental contamination by heavy metals, DDTs and PCBs.

The influence of temperature on enzyme activities has been reported in different bivalve species (Dellali et al., 2001; Pfeifer et al., 2005). Temperature was positively correlated with AChE activities (Tables 2 and 3). Although the range of temperatures (Table 1) recorded in this study could not be regarded as representative of high thermal stress (very little temperature difference observed between sites), they can be considered to be an additional stress to pollutant exposure. 
It has also become evident that instead of using single biomarkers it is more appropriate to apply them as a battery (Bolognesi et al., 2004, Galloway et al., 2004, Shiedek et al., 2006). The application of a suite of sensitive and integrative biomarkers could clearly differentiate between healthy and stressed organisms (Brooks et al., 2011), allowing a more precise differentiation of pollution hazards and possible health risk for exposed organisms.

Table1:- Temperature and $\mathrm{pH}$ measurements on the sampling stations.

\begin{tabular}{|c|c|c|}
\hline Station & Temperature $\left({ }^{\circ} \mathrm{C}\right)$ & $\mathrm{pH}$ \\
\hline S1 & 19.2 & 8.15 \\
\hline S2 & 19.5 & 8.1 \\
\hline S3 & 21.6 & 8.23 \\
\hline S4 & 20 & 8.29 \\
\hline S5 & 17.8 & 8.4 \\
\hline
\end{tabular}

Table 2:- Pearson correlation coefficients and biochemical and environmental variables.

\begin{tabular}{|c|c|c|c|c|c|c|}
\hline & MT & AChE & GST & MDA & T & $\mathrm{pH}$ \\
\hline MT & 1 & -0.009 & 0.239 & 0.947 & 0.074 & 0.647 \\
\hline AChE & & 1 & -0.895 & -0.140 & 0.765 & -0.491 \\
\hline GST & & & 1 & 0.344 & -0.423 & 0.545 \\
\hline MDA & & & & 1 & -0.042 & 0.506 \\
\hline T & & & & & 1 & -0.366 \\
\hline pH & & & & & & 1 \\
\hline
\end{tabular}

Numbers in bold indicate significant correlation at $\mathrm{p}<0.05$

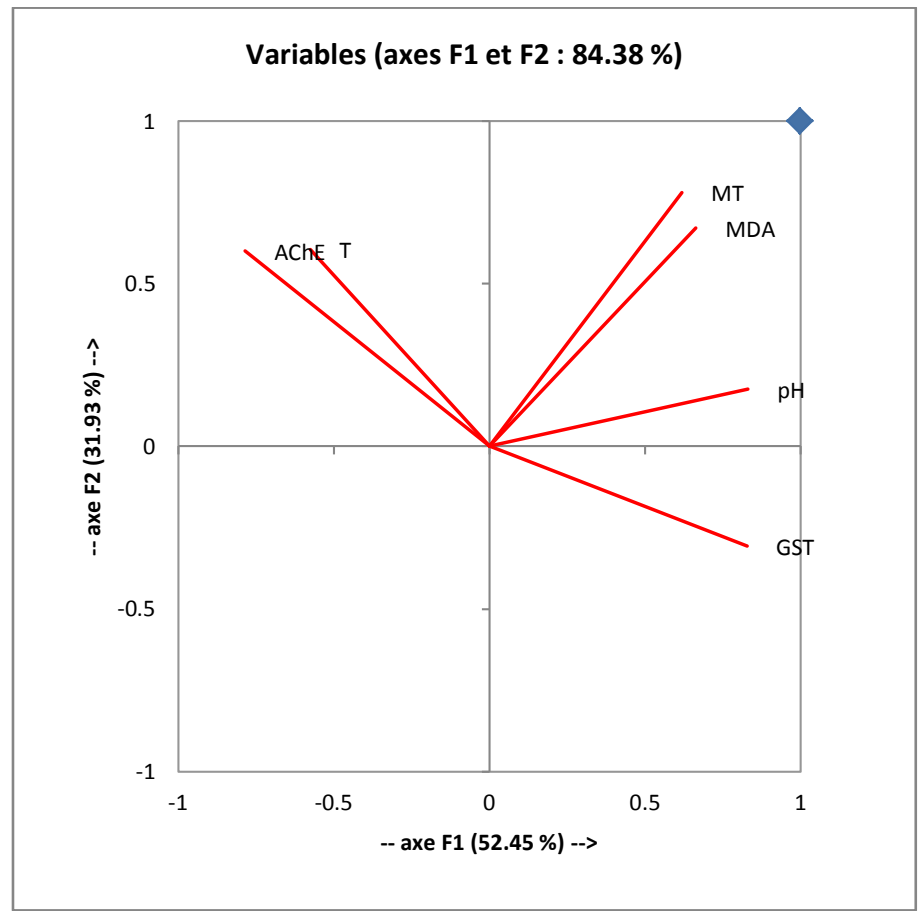




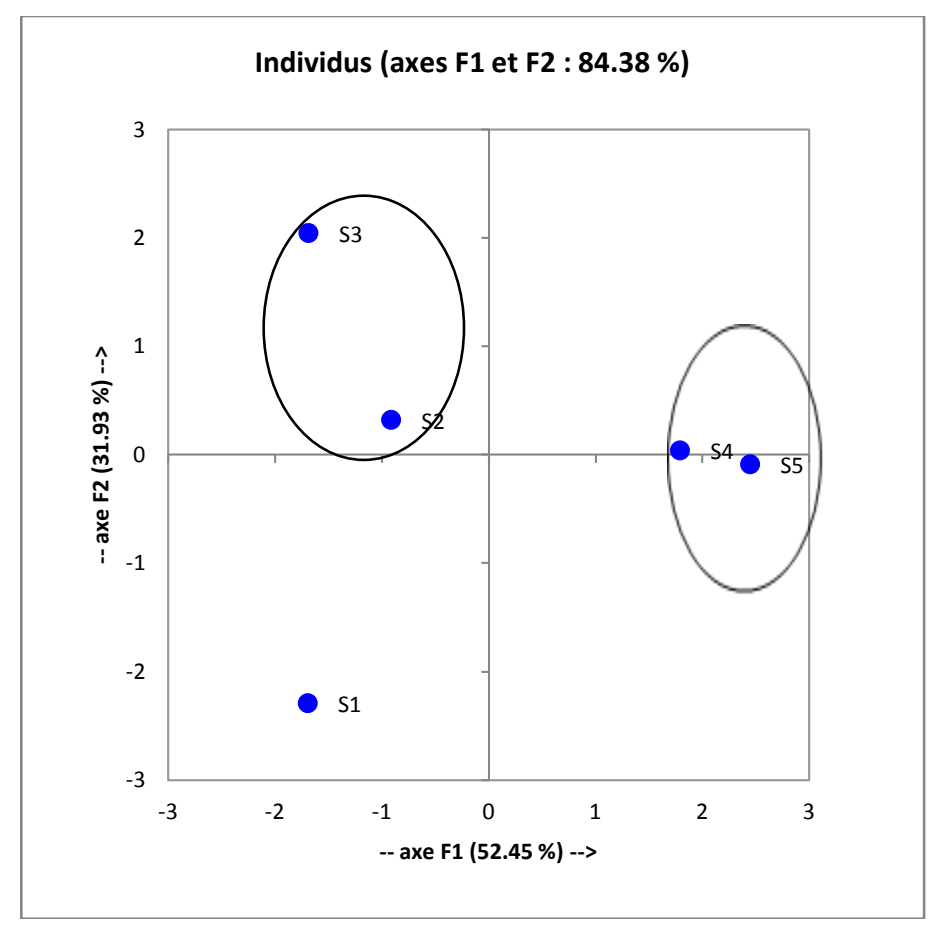

Fig 3:- Results of the PCA for two principal components produced by biochemical (AChE, GST, MDA, MT and environmental $(\mathrm{T}, \mathrm{pH})$ variables) in mussels collected at six stations in the Moroccan Atlantic center coast.

Principal Component analysis (Figure 3) allowed the identification of variables that had a major contribution to the total variance of the data set.

Out of all the studied parameters, revealing three groups of stations. The first one includes mussels from S1 with low MDA and MT activities. The second encompasses the most polluted stations (S4 and S5) with high MT and MDA activities and low AChE activities. Lastly, mussels from the least polluted stations (S2 and S3) characterized by moderate MDA and MT levels, low GST activity and high AChE level and this confirms our results. Person's correlation (Table 2) and PCA (Figure 3) showed that MDA and MT biomarkers are significantly positively correlated and GST and AChE are significantly negatively correlated.

\section{Conclusion:-}

This study provides concordant information on the presence of contaminants, attesting by biological responses on mussels. The battery of parameters applied in this study includes AChE, GST, MT and MDA activities in digestive gland. This study allowed three groups of stations along the Moroccan center Atlantic coast according to the biological responses in mussels, and showed significant correlations between two groups of biomarkers. It is proposed to use it as a valuable tool to compare the marine ecosystem states over other sites of the Mediterranean and East Atlantic sites. These results demonstrate that this area is under the influence of different pollution sources and that M. galloprovincialis constitutes a suitable bioindicator species for biomonitoring.

\section{Acknowledgment:-}

I want to thank the Quality and Safety of the Marine Environment INRH Department and the Oualidia INRH station.

\section{References:-}

1. Andrews, G.K., 2000. Regulation of metallothionein, gene expression by oxidative stress and metal ions. Biochem. Pharm. 59, 95-104.

2. Barhoumi, B., Le Menach, K., Clérandeau, C., Ben Ameur, W., Budzinski, H., Driss, M.R., Cachot, J., 2014. Assessment of pollution in the Bizerte lagoon (Tunisia) by the combined use of chemical and biochemical markers in mussels, Mytilus galloprovincialis. Mar. Pollut. Bull. 84, 379-390. 
3. Benbrahim, S., Chafik, A., Chfiri, R., Bouthir, F.Z., Siefeddine, M., Makaoui, A., 2006. Etude des facteurs influençant la répartition géographique et temporelle de la contamination des côtes atlantiques marocaines par les métaux lourds: cas du mercure, du plomb et du cadmium. Mar. Life. 16, 37-47.

4. Binelli, A., Ricciardi, F., Provini, A., 2006. New evidences for old biomarkers: effects of several xenobiotics on EROD and AChE activities in Zebra mussel (Dreissena polymorpha). Chemosphere 62, 510-519.

5. Bolognesi, C., Frenzilli, G., Lasagna, C., Perrone, E., Roggieri, P., 2004. Genotoxicity biomarkers in Mytilus galloprovincialis: wild versus caged mussels. Mut. Res. 552, 153-162.

6. Bouthir F.Z, Chafik, A., Benbrahim, S., Souabi, S., Mardhy, H., Messoudi, A., 2004.Qualité physico-chimique des eaux côtières du littoral de la Wilaya du grand Casablanca (océan Atlantique marocain) utilisant la moule Mytilus galloprovincialis comme indicateur de la contamination métallique Mar. Life, 14, 59-70.

7. Bradford, M., 1976. A rapid and sensitive method for the quantification of microgram quantities of protein utilizing the principle of protein-dye blinding. Anal. Biochem. 72, 248-254.

8. Brooks, S., Harman, C., Zaldibar, B., Izagirre, U., Glette, T., Marigomez, I., 2011. Integrated biomarker assessment of the effects exerted by treated produced water from an onshore natural gas processing plant in the North Sea on the mussel Mytilus edulis. Mar. Pollut. Bull. 62, 327-339.

9. Canesi, L., Viarengo, A., Leonzio, C., Filippelli, M., Gallo, G., 1999. Heavy metals and glutathione metabolism in mussel tissues. Aquat. Toxicol. 46, 67-76.

10. Capela, R., Raimundo, J., Santos, MM., Caetano, M., Micaelo, C., Vale, C., Guimaraes, L., Reis-Henriques, M.A., 2016. The use of Biomarkers as integrative tools for transitional water bodies monitoring in the Water Framework Directive Context- A holistic approach in Minho river transitional waters. Sci. Tot. Envir. 539, 8586.

11. Chafik, A., Cheggour, M., Cossa, D., Sifeddine, S.B.M., 2001. Quality of Moroccan Atlantic coastal waters: water monitoring and mussel watching. Aquat. Living Resour. 14, 239-249.

12. Charouf, L. 1986. Les problèmes d'ensablement des ports Marocains sur la façade atlantique : Leur impact sédimentologique sur le littoral. Ph. D. thesis, Paris-Sud Univ., Orsay, France, 312 p.

13. Cheggour, M., Langston, W.J., Chafik, A., Texier, H., Idrissi, H., Boumezzough, A., 1999. Phosphate industry discharges and their impact on metal contamination and intertidal macrobenthos: Jorf Lasfar and Safi coastlines (morocco). Toxicol. Environ. Chem.70, 159-179.

14. Cossu-Leguille,C., Vasseur,P., 2013. Aquatic biomarkers, in Férard,J.F.,Blaise,C. (Eds), Encyclopedia of Aquatic Ecotoxicology, vol. 1, Springer, Dordrecht, Netherlands, pp. 49-66.

15. De Luca-Abbott, S.B., Richardson, B.J., McClellan, K.E., Zheng, G.J., Martin, M., Lam, P.K.S., 2005. Field validation of antioxidant enzyme biomarkers in mussels (Perna viridis) and clams (Ruditapes philippinarum) transplanted in Hong Kong coastal waters. Mar. Pollut. Bull. 51, 694-707.

16. Dellali, M., Gnassia Barelli, M., Romeo, M., Aissa, P., 2001. The use of acetylcholinesterase activity in Ruditapes decussatus and Mytilus galloprovincialis in the biomonitoring of Bizerta lagoon. Comp. Biochem. Phys. C 130, 227-235.

17. Ellman, G.L., Courtney, K.D., Andreas, V., Featherstone, R.M., 1961. A new and rapid colorimetric determination of AChE activity. Biochem. Pharmacol. 7, 88-95.

18. Fernandez, B., Campillo, J.A., Martinez-Gomez, C., Benedicto, J., 2010. Antioxidant responses in gills of mussel (Mytilus galloprovincialis) as biomarkers of environmental stress along the Spanish Mediterranean coast. Aquat. Toxicol. 99, 186-197.

19. Fulton, MH., Key, PB. 2001. Acetylcholinesterase inhibition in estuarine fish and invertebrates as an indicator of organophosphorus insecticide exposure and effects. Environ. Toxicol. Chem. 20, 37-45.

20. Galgani, F., Bocquené, G., 1989. A method for routine detection of organophosphates and carbamates in sea water. Environ. Technol. Lett. 10, 311-322.

21. Galloway, T.S., Brown, R.J., Browne, M.A., Dissanayake, A., Lowe, D., Depledge, M.H., 2004. A multibiomarker approach to environmental assessment. Environ. Sci. Technol. 38, 1723-1731.

22. Géret, F., Jouan, A., Turpin, V., Bebianno, M.J., Cosson, R.P., 2002. Note. Influence of metal exposure on metallothionein synthesis and lipid peroxidation in two bivalves mollusks: the oyster (Crassostrea gigas) and the mussel (Mytilus edulis). Aquat. Living Resour. 15, 61-66.

23. Guilhermino, L., Barros, B., Silva, M.C., Soares, A.M.V.M., 1998. Should the use of inhibition of cholinesterases as a specific biomarker for organophosphate and carbamate pesticides be questioned? Biomarkers 3, 157-163.

24. Habig, W.H., Pabst, M.J., Jakobi, W.B., 1974. Glutathione S-transferases: the first enzymatic step in mercapturic acid formation. J. Biol. Chem. 249, 7130-7139. 
25. Hagger, J.A., Galloway, T.S., Oehlmann, J., Jobling, S., Depledge, M.H., 2006. Is there a causal association between genotoxicity and the imposex effects? Environ. Health Perspect. 114, 20-26.

26. Hamza-Chaffai, A., 2014. Usefulness of Bioindicators and Biomarkers in Pollution Biomonitoring. Int. J. Biotechnol. Wellness Ind. 3, 19-26.

27. He, X., Nie, X., Wang, Z., Cheng, Z., Li, K., Li, G., Wong, M.H., Liang, X., Tsui, M.T.K., 2011. Assessment of typical pollutants in waterborne by combining active biomonitoring and integrated biomarkers response. Chemosphere 84, 1422-1431.

28. ICES, 2008. Report of the Fourth ICES/OSPAR Workshop on Integrated Monitoring of Contaminants and their Effects in Coastal and Open Sea Areas (WKIMON IV), 5- 7 February 2008. ICES, Copenhagen, Denmark. ICES CM 2008/ACOM: 49, 71.

29. Jayed, M., Chafik, A., Benbrahim, S., Vale, C., Bakkas, S., Pereira, P., Ferreira, M., 2010. Polychlorinated biphenyls and chlorinated pesticides in the mussel Mytilus galloprovincialis sampled along the Moroccan Atlantic Coast. Journal of Oceanography and Marine science 1, 93-98.

30. Jeng, M.C., Jeng, W.L., Hung, T.C., Yeh, C.Y., Tseng, R.J., Meng, P.J., Han, B.C., 2000. Mussel Watch: a review of $\mathrm{Cu}$ and other metals in various marine organisms in Taiwan, 1991-98. Environ. Poll. 110, 207-215.

31. Kaimoussi, A., Chafik, A., Cheggour, A., Mouzdahir, A., Bakkas, S., 2000. Variations saisonnières des concentrations en métaux $(\mathrm{Cd}, \mathrm{Cu}, \mathrm{Zn}, \mathrm{Fe}$ et $\mathrm{Mn}$ ) chez la moule Mytilus galloprovincialis du littoral de la région d'Eljadida (Maroc) Mar. Life 10, 77-85.

32. Khessiba, A., Hoarau, P., Gnassia-Barelli, M., Aissa, P., Roméo, M., 2001. Biochemical response of the mussel Mytilus galloprovincialis from Bizerta (Tunisia) to chemical pollutant exposure. Archives of Environ. Contam. Toxicol. 40, 222-229.

33. Knight, J.A., Pieper, R.K., McClellan, L., 1988. Specificity of the thiobarbituric acid reaction: its use in studies of lipid peroxidation. Clin. Chem. 34, 2433-2438.

34. Labrot, F., Ribera, D., Saint Denis, M., Narbonne, J.F., 1996. In vitro and in vivo studies of potential biomarkers of lead and uranium contamination: lipid peroxidation, acetylcholinesterase, catalase and glutathione peroxidase activities in three non mammalian species. Biomarkers 1, 21-28.

35. Langston, W.J., Bebianno, M.J., Burt, G.R., 1998. Metal Handling strategies in molluscs. In: Langston, W.J., Bebianno, M.J. (Eds.), Metal metabolism in aquatic environments. Chapman Hall, London, 8, 219-284.

36. Lehtonen, K.K., Leiniö, S., Schneider, R., Leivuori, M., 2006. Biomarkers of pollution effects in the bivalves Mytilus edulis and Macoma balthica collected from the southern coast of Finland (Baltic Sea). Mar. Ecol. Prog. 322, 155-168.

37. Livingstone, D.R., 1993. Biotechnology and pollution monitoring: use of molecular biomarkers in the aquatic environment. J. Chem. Technol. Biot. 57, 195-211.

38. Livingstone, D.R., Donkin, P., Walker, C.H., 1992. Pollutants in marine ecosystems: an overview. In: Walker, C., Livingstone, D.R. (Eds.), Persistent Pollutants in Marine Ecosystems, SETAC Special Publications Series. Pergamon Press, 235-263.

39. Maanan, M., 2007. Biomonitoring of heavy metals using Mytilus galloprovincialis in Safi coastal waters. Morocco. Environ. Toxicol. 22, 525-531.

40. Maanan, M., 2008. Heavy metal concentrations in marine molluscs from the Moroccan coastal region. Environ. Pollut. 153, 176-83.

41. Marnett, L.J., 1999. Lipid peroxidation - DNA damage by malondialdehyde. Mut. Res. 424, 83-95.

42. McCarthy, J.F., Shugart, L.R., 1990. Biological markers of environmental contamination. In: McCarthy, J.F., Shugart, L.R. (Eds.), Biomarkers of Environmental Contamination. Lewis Publisher, Boca Raton, FL, 3-16.

43. Mora, P., Michel, X., Narbonne, J.-F., 1999. Cholinesterase activity as potential biomarker in two bivalves. Environ. Toxicol. Pharmacol. 7, 253-260.

44. Moreira, S., Guilhermino, L., 2005. The use of Mytilus galloprovincialis, acetylcholinesterase and glutathione S-transferases activities as biomarkers of environmental contamination along the northwest Portuguese coast. Environ. Monit. Assess. 105, 309-325.

45. Moustaid, K., Nasser, B., Baudrimont, I., Anane, R., El Idrissi, M., Bouzidi, A., 2005. Évaluation comparée de la toxicité des moules (Mytilus galloprovincialis) de deux sites du littoral atlantique marocain sur des souris. C. R. Biol. 328, 281-289.

46. Narbonne, J.F, Daubeze, M., Clérandeau, C. Garrigues, P., 1999. Scale of classifacation based on biochemical markers in mussels : application to pollution monitoring in European coasts. Biomarkers 4, 415-424.

47. Office Chérifien des Phosphates, Annual Report, Maroc. http://www.ocpgroup.ma/finance/rapportspublies/rapport-annuel, 2012.OSPAR, 2000. Quality Status Report: Region IV - Bay of Biscay and Iberian Coast. OSPAR Commission, London. 
48. Parolini, M., Pedriali, A., Riva, C., Binelli, A., 2013. Sub-lethal effects caused by cocaine metabolite benzoylecgonine to the freshwater mussel Dreissena polymorpha. Sci. Tot. Envir. 444, 43-50.

49. Pellerin-Massicotte, J., 1997. Influence of elevated temperature and air exposure on MDA levels and catalase activities in digestive glands of the blue mussel (Mytilus edulis L.). J. Rech. Océanogr. 22, 91-98.

50. Pfeifer, S., Schiedek, D., Dippner, J.W., 2005. Effect of temperature and salinity on acetylcholinesterase activity, a common pollution biomarker, in Mytilus sp. from the south-western Baltic Sea. J. Exp. Mar. Biol. Ecol. 10, 41-47.

51. Schiedek, D., Broeg, K., Barsiene, J., Lehtonen, K.K, Gercken, J., Pfeifer, S., Vuontisjarvi, H., Vuorinen, P.J., Dedonyte, V.,Koehler, A., Balk, L., Schneider, R., 2006. Biomarker responses as indication of contaminant effects in blue mussel (Mytilus edulis) and female eelpout (Zoarces viviparus) from the southwestern Baltic Sea. Mar. Poll. Bull. 53, 387-405.

52. Serafim, A., Lopes, B., Company, R., Cravo, A., Gomes, T., Sousa, V., Bebianno, M.J., 2011. A multibiomarker approach in cross-transplanted mussels Mytilus galloprovincialis. Ecotoxicology 20, 1959-1974.

53. Stohs, S.J., Bagachi, D., Hassoun, E., Bgachi, M., 2000. Oxidative mechanism in the toxicity of chromium and cadmium ions. J. Environ. Pathol. Toxicol. Oncol. 19, 201-213 .

54. Sunderman, F.W, Marzouk, A., Hopper, S.M., Zaharia, O., Reid, M.C., 1985. Increased lipid peroxidation in tissues of nickel chloride-treated rats. Ann. Clin. Lab. Sci. 15, 229-236.

55. Thornalley, P., Vašák, M., 1985. Possible role for metallothionein in protection against radiation induced oxidative stress. Kinetics and mechanism of its reaction with superoxide and hydroxyl radicals. BBA-Protein Structure and Molecular Enzymology 827, 36-44.

56. Tim-Tim, ALS., Morgado, F., Moreira, S., Rangel, R., Nogueira, AJA., Soares, AMM., 2009. Cholinesterase and glutathione S-transferase activities of three mollusc species from the NW Portuguese coast in relation to the 'Prestige' oil spill. Chemosphere 77, 1465-1475.

57. Torres, M.A., Testa, C.P., Gaspari, C., Masutti, M.B., Panitz, C.M.N., Curi-Pedrosa, R., Almeida, E.A., Di Mascio, P., Wilhelm Filho, D., 2002. Oxidative stress in the mussel Mytella guyanensis from polluted mangroves on Santa Catarina Island. Brazil. Mar. Poll. Bull. 44, 923-932.

58. Viarengo, A., Burlando, B., Ceratto, N., Panfili, I., 2000. Antioxidant role of metallothioneins: a comparative overview. Cell. Mol. Biol. 46, 407-417.

59. Viarengo, A., Canesi, L., 1991. Mussels as biological indicators of pollution. Aquaculture 94, 225-243.

60. Viarengo, A., Canesi, L., Pertica, M., Poli, G., Moore, M.N., Orunesu, M., 1990. Heavy metal effects on lipid peroxidation in the tissues of Mytilus galloprovincialis Lam. Comp. Biochem. Physiol. 97C, 37-42.

61. Viarengo, A., Ponzano, E., Dondero, F., Fabbri, R., 1997. A simple spectrophotometric method for metallothionein evaluation in marine organisms: an application to Mediterranean and Antarctic molluscs. Mar. Environ. Res. 44, 69-84.

62. Vidal-Linan, L., Bellas, J., Campillo, J.A., Beiras, R., 2010. Integrated use of antioxidant enzymes in mussels, Mytilus galloprovincialis, for monitoring pollution in highly productive coastal areas of Galicia (NW Spain). Chemosphere 78, 265-272.

63. Won, S., Novillo, A., Custodia, N., Rie, M.T., Fitzgerald, K., Osada, M., Callard, A.P., 2005. The freshwater mussel (Elliptio complanata) as a sentinel species: vitellogenin and steroid receptors. Integr. Comp. Biol. 45, $72-80$. 